\title{
Detection of Phytophthora ramorum in Nurseries and Forest Lands in California in 2004 to 2009
}

C. L. Blomquist, L. E. Yakabe, and S. Rooney-Latham, California Department of Food and Agriculture, Plant Pest Diagnostics Center, Sacramento 95832; and N. McRoberts and C. Thomas, Department of Plant Pathology, University of California, Davis 95616

\begin{abstract}
Blomquist, C. L., Yakabe, L. E., Rooney-Latham, S., McRoberts, N., and Thomas, C. 2016. Detection of Phytophthora ramorum in nurseries and forest lands in California in 2004 to 2009. Plant Dis. 100:139-148.

From December 2004 through May 2009, samples were collected from California nurseries and wild lands to survey for Phytophthora ramorum and comply with federal regulations of nursery stock. Samples were prescreened by an enzyme-linked immunosorbent assay (ELISA) that detects Phytophthora spp. and tested by culture, $P$. ramorum-specific real-time polymerase chain reaction (PCR), and nested PCR. Yearly percentages of infected samples ranged from 0.6 to $2.3 \%$. Camellia spp., Rhododendron spp., Magnolia spp., Pieris spp., and Laurus nobilis tested positive the most frequently in the nurseries and Lithocarpus densiflorus, Umbellularia californica, and Quercus agrifolia tested positive most often from wild

lands. Of the 118,410 samples isolated onto PARP media, $0.8 \%$ was identified as $P$. ramorum. Of 115,056 samples tested by ELISA, $5.9 \%$ tested positive for Phytophthora spp. Of the 6,520 samples tested by PCR, $12.4 \%$ tested positive for $P$. ramorum. The false-negative, positive, and internal control failure rates of the assays are discussed. After removing the seasonal effect of sampling strategy, isolation of the pathogen into culture was found to be seasonally dependent whereas detectability by PCR and ELISA was not. To our knowledge, this is the first evaluation of a regulatory testing program for a plant pathogen on this scale using standardized assays.
\end{abstract}

Phytophthora ramorum Werres, de Cock \& Man in't Veld was described as a new species in 2001 (Werres et al. 2001) and is recognized as the cause of sudden oak death in some oak species and ramorum blight of many woody plant species in California (Davidson et al. 2003). The pathogen now exists in the environment in portions of 15 counties of coastal California and in one county in Oregon. It can infect more than 100 host species from more than 40 genera, mostly woody plant hosts (Grunwald et al. 2008; Rizzo et al. 2005). The discovery of $P$. ramorum in ornamental plant nurseries in Washington, Oregon, and California and the shipment of infected nursery plants from these three states to other states led to regulation by the United States Department of Agriculture Animal Pest Health Inspection Service (USDA-APHIS) with rule 7CFR Ch III 301.92. This rule requires nurseries in California, Oregon, and Washington to be inspected, tested, and found free from P. ramorum before they can ship host and associated host plants out of the state in which they were produced. Host species are defined as plant species where $P$. ramorum has been isolated in culture and on which Koch's postulates have been verified; associated hosts are species from which $P$. ramorum has been isolated in culture or detected by polymerase chain reaction (PCR) only and no plant inoculation studies have been completed. Since the initial emergency order was adopted in 2004, $P$. ramorum has been found in nurseries, in limited areas of the natural environment near nurseries, and in waterways outside of California, Oregon, and Washington (Chastagner et al. 2010; Frankel and Hansen 2011).

On 31 March 2014 a new Federal order, DA-2014-02, was adopted which substantially changes the regulation of $P$. ramorum in the nurseries. These regulations require the inspection and testing of host and associated host plants only from nurseries in which $P$. ramorum

Corresponding author: C. Blomquist; E-mail: cheryl.blomquist@cdfa.ca.gov

*The $\boldsymbol{e}$-Xtra logo stands for "electronic extra" and indicates that four supplementary figures and one supplementary table are published online.

Accepted for publication 30 April 2015.

http://dx.doi.org/10.1094/PDIS-12-14-1302-RE

(C) 2016 The American Phytopathological Society has been detected in the last 3 years. Nursery inspections at these previously positive sites involves a more rigorous survey and more extensive sampling of plants and standing water than under previous regulations. These recent regulations now pertain to all nurseries that ship across state lines in the United States, not only those located in Washington, Oregon, and California. Yearly testing of nurseries in the 15 counties in California and 1 county in Oregon where $P$. ramorum is known to occur in the wild lands will continue to be required (Anonymous 2014).

The nursery industry in California had a farm gate value of $\$ 3.78$ million in 2009 (Anonymous 2011). Nursery producers sell and ship host, associated, and nonhost plants to customers located out of state. Prior to 2014, if the pathogen was confirmed in a nursery, a destruction block consisting of a continuous block of host plants was delimited and destroyed. The surrounding plants within $10 \mathrm{~m}$ of the destruction block were held for inspection over a 90-day period. The economic impact to the plant grower due to plant destruction and plants being held off sale during the 90 -day period can be substantial. More than 1 million plants were destroyed when P. ramorum was detected in 2004 in a large wholesale nursery in California. Estimated losses, including credits to customers, cost of cleanup, cost of inventory, and lost sales, were $\$ 6.9$ million. (J. Keller, personal communication). The economic and environmental impact of introducing the pathogen into a new state or a new susceptible forest environment can have serious environmental consequences. $P$. ramorum has been recently reported causing damage on approximately 0.5 million Japanese plantation larch trees in the United Kingdom (Brasier and Webber 2010; Webber et al. 2010).

To assure that all nurseries within the regulated states were being treated uniformly and the samples tested accurately, pathogen testing protocols were standardized and validated with a large number of samples. Under the federal rule, only assays approved by USDAAPHIS may be used for regulatory testing. In this study, we wanted to evaluate the false-positive, negative, and failure rates for each of the assays as they compare with our standard assay. We also wanted to determine which host plant species were most commonly infected in the nurseries. We also hypothesized that there was a seasonal variation in $P$. ramorum infection in the nurseries and in the forest. To our knowledge, this is the first evaluation of a regulatory testing program for a plant pathogen on this scale using standardized assays. 


\section{Materials and Methods}

Nursery surveys. Ornamental nurseries from counties in California were surveyed for leaf spots and twig blights as part of the mandated nursery surveys conducted by the California Department of Food and Agriculture (CDFA) and the local county agricultural commissioners to detect $P$. ramorum. From December 2004 through May 2009, nursery samples were collected from wholesale and retail nurseries by trained county agricultural biologists. All samples were collected and processed in accordance with the APHIS survey and sampling protocol that requires all regulated host plants and hosts associated with $P$. ramorum be visually inspected for leaf lesions and twig blights. Although sampling was biased toward these hosts, all other plants showing obvious leaf lesions and twig blights also were sampled. Individual plant samples containing anywhere from 1 to 80 leaves from a single species or variety block were bagged separately in moistureretaining containers, kept at $4^{\circ} \mathrm{C}$, shipped at ambient temperature, and sent to the CDFA laboratory for further processing. For the purposes of this study, a sample lot is defined as a group of samples from one growing ground during one sampling event. Each lot typically contained anywhere from 1 to 50 individual plant samples.

USDA detections by host. Plant samples suspected to be infected with $P$. ramorum collected from nurseries by regulatory officials were sent to the USDA-APHIS Plant Protection and Quarantine (PPQ) testing laboratory in Beltsville, MD for confirmation over the study time period. Samples were tested using the same protocols described below.

Forest sampling. Samples were collected by county agricultural biologists, foresters, homeowners, park managers, and farm advisors from infested and uninfested counties. Trinity County was determined to be an infested county in 2014, after this study was completed. We recommended that samples be submitted from January to August for the best possibility for detection, although we tested samples submitted outside this time frame. Umbellularia californica samples were sent in as leaves. Quercus agrifolia and Lithocarpus densiflorus samples were sent in as bark canker pieces sampled from necrotic margins and isolated onto CMA-PARP, a semiselective medium for Phytophthora (Jeffers and Martin 1986) on site, and sent by overnight mail to our laboratory for incubation. Isolation plates were examined for growth from 7 to

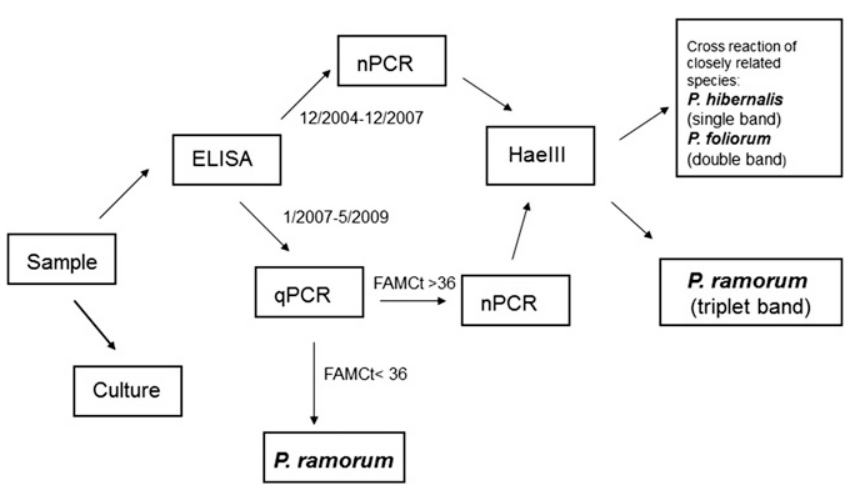

Fig. 1. Flow chart for testing of nursery samples for Phytophthora ramorum at the California Department of Food and Agriculture Laboratory. Five 4-mm² lesion margins from symptomatic plants or the same size pieces from healthy plants are selected and divided. Half of each of the five pieces were placed on PARP semiselective media and half were tested by an Agdia Phytophthora spp. enzymelinked immunosorbent assay (ELISA). If the optical density at $405 \mathrm{~nm}$ from the ELISA test measures more than twice the background, the lesion margins are resampled from the original plant sample and DNA is extracted. Before January 2007, the DNA extract was tested by nested polymerase chain reaction (nPCR). After January 2007, the DNA extract was tested by a real-time PCR (qPCR). If the FAM cycle threshold $(\mathrm{Ct}) \leq 36$, the sample is considered positive. If the sample FAM $\mathrm{Ct} \geq 36$, the DNA extract is tested by $\mathrm{nPCR}$. If a band is produced in the $\mathrm{nPCR}$ test, the test is positive. The amplicon from the nPCR test is later digested by Haelll to confirm the identity of the product.
14 days after the sample was taken. Occasional leaf and stem samples were also received from $L$. densiflorus and sampled in the lab. No effort was made to control the numbers or locations from which the samples were taken.

Enzyme-linked immunosorbent assay. Five or six pieces, 8 to 12 by 5 to $6 \mathrm{~mm}$ in size, were cut from the lesion margins from leaves or stems from each sample bag. The number of leaves sampled from each sample bag ranged from one to six, depending on the symptoms and the number of leaves collected. Each of the pieces was divided into two, each half containing equal amounts of necrotic and healthy tissue. One set of halves were plated directly on CMA-PARP. The other halves of these pieces were ground in $1 \mathrm{ml}$ of GEB2 buffer (Agdia, Elkhart, IN) using a Fast Prep machine (MP Biomedical, Solon, $\mathrm{OH}$ ) and $100 \mu \mathrm{l}$ of the grindate was tested in duplicate using a Phytophthora spp.-specific enzyme-linked immunosorbent assay (ELISA) kit (catalog number PSA 92600; Agdia). Tests were run according to manufacturer instructions. ELISA tests were considered positive and tested further by PCR if the optical density at $405 \mathrm{~nm}$ was at least twice the negative control.

Isolation. Isolation plates were stored at room temperature (20 to $25^{\circ} \mathrm{C}$ ) in the dark and monitored for hyphal growth for up to 14 days. Cultures were identified as $P$. ramorum by distinct colony morphology with corroloid hyphae, chlamydospores, and the occasional presence of semipapilate cauducous sporangia. Sometimes a culture of $P$. ramorum grew from a sample before PCR could be performed. In this case, the sample was considered positive and PCR was not performed to save time and resources. $P$. hibernalis (Erwin and Ribeiro 1996; Waterhouse and Waterston 1964) and $P$. foliorum (Donahoo et al. 2006) were identified by morphological characteristics and confirmed by sequence analysis.

DNA extraction. DNA was extracted from samples that tested ELISA positive using the DNeasy Plant Mini Kit (catalog number 69106; Qiagen, Valencia, CA) using the protocol for plant samples.

Nested PCR. PCR was performed according to the USDA-APHIS protocol. The nested PCR (nPCR) test specific for $P$. ramorum is a variation of the nPCR assay originally developed by Hayden et al. (2004). A sample is considered positive when, in a twostep reaction, an amplicon of $291 \mathrm{bp}$ is produced. The control reaction for this test, which is performed in parallel to the nPCR, uses the PCR test for P. lateralis (Winton and Hansen 2001), which includes the ribosomal DNA (rDNA) universal primers NS1 and NS2 as internal controls. The detection primers in the Winton and Hansen test will amplify $P$. ramorum, $P$. lateralis, and $P$. hibernalis DNA but, due to reduced sensitivity in amplification of $P$. ramorum compared with the nPCR test, its results are not used for final determination. If an amplicon of approximately $550 \mathrm{bp}$ is not produced by the internal control primers, the results are scored as an internal control failure for the nPCR test.

Real-time PCR. The real-time PCR (qPCR) test was implemented after January 2007 and is a variation of Hughes et al. (2006). The multiplex qPCR test uses primers which amplify a portion of the rDNA gene of $P$. ramorum and another set of primers which amplify a portion of the plant cox gene which serves as an internal control. After January 2007, when the qPCR test became the primary test, if the FAM cycle threshold $(\mathrm{Ct})$ was 0 and the internal control $\mathrm{Ct}$ was $<36$, the sample was considered negative. If the FAM Ct in the qPCR test was $\leq 36$ and the internal control $\mathrm{Ct}$ was $<36$, the sample was considered positive. If the $\mathrm{Ct}$ for the qPCR test was $>36$, the DNA sample was tested further by the nPCR test (Fig. 1). If the subsequent nPCR tests were positive, the sample was positive. If a sample tested negative by nPCR (no amplicon was produced or none of the right size), the sample was considered negative (Fig. 1). An internal control was considered a failure if the $\mathrm{Ct}$ for the cox gene test was $\geq 36$ after one test.

Hae III digestion. The nPCR test sometimes produced an amplicon when $P$. hibernalis or $P$. foliorum was present due to cross 
amplification (Blomquist et al. 2005). To distinguish between these species and $P$. ramorum, a restriction fragment length polymorphism (RFLP) was developed using the restriction enzyme HaeIII. On digestion of the $\mathrm{nPCR}$ product with HaeIII, $P$. ramorum produces three distinct bands, $P$. foliorum produces a doublet, and $P$. hibernalis produces a single band (Blomquist et al. 2005).

Time series analysis. As described above, the complete diagnostic process included several components (ELISA, PCR, and isolation of the pathogen into culture), each of which contributed to the final determination of pathogen status and, hence, to the data for that category. One of the important practical issues that arose during the pathogen response period was whether these different diagnostic approaches, and the final determination, were affected by seasonal variation. A time series analysis approach was used to examine this question and to compare the temporal patterns of positive diagnoses (for each diagnostic technique) for forest and nursery samples. The time series for forest and nursery samples were analyzed to study their separate autocorrelation structures and their cross-correlation structure (i.e., the correlation between the two series at different lag times). The presence of significant autocorrelation in a time series indicates two important properties. First, it may indicate the presence of periodicity, or seasonality, in the data, so that observations separated by particular intervals tend to be similar to each other. Second, it may suggest the presence of a process which causes observations at later time points to be dependent upon or, to some extent, predictable from earlier ones (Crawley 2013; Royama 1992). The process and rationale of the analysis was as follows.

The raw data series of numbers of confirmed positive cases of $P$. ramorum (for each of the diagnostic tests) and their autocorrelation functions $(\mathrm{ACF})$ are presented in the e-Xtra material but are

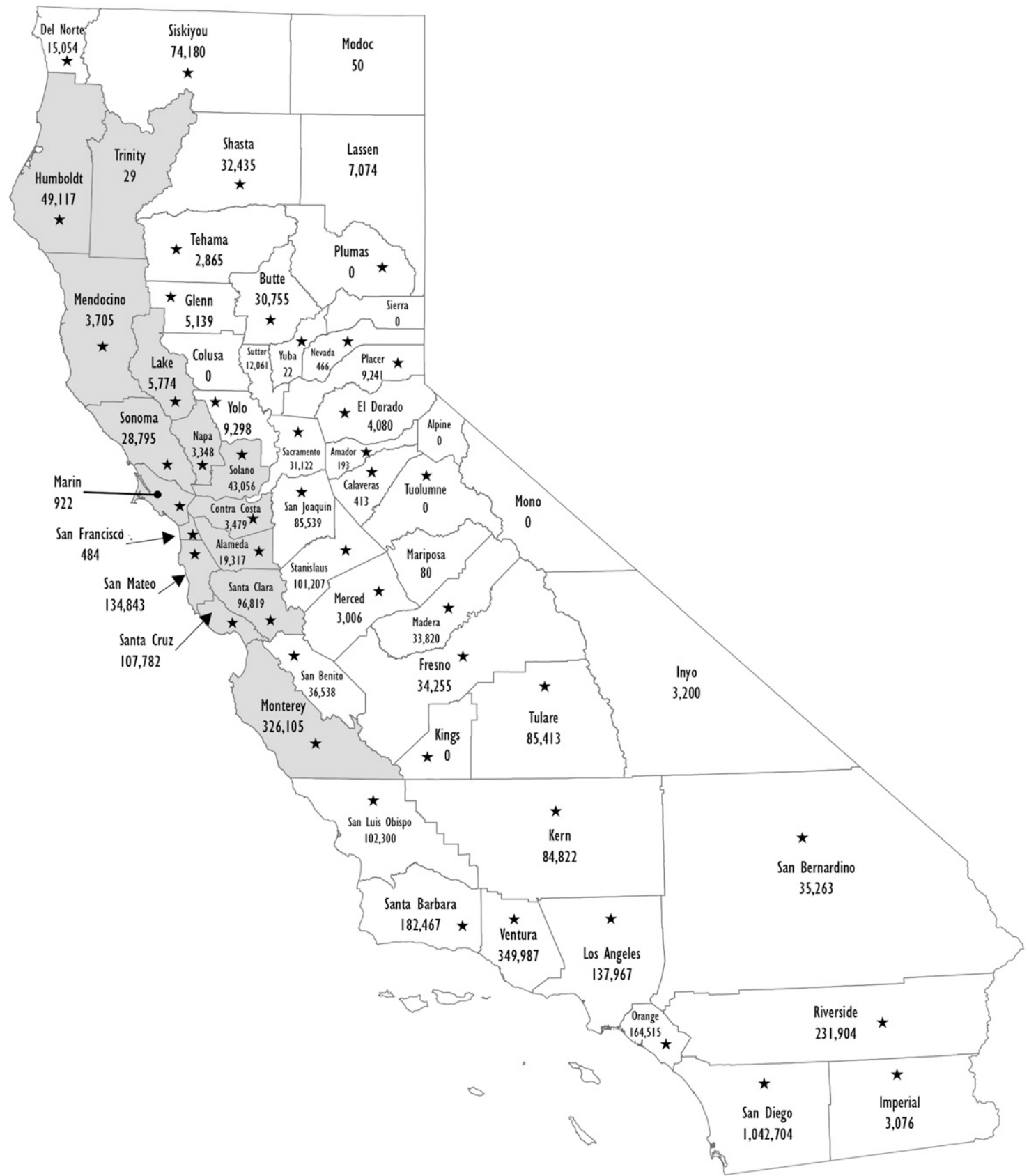

Fig. 2. Pictorial map of the location by California counties where nurseries were sampled from June 2004 to May 2009 for Phytophthora ramorum are marked with a star. Total Farmgate value of nursery and floral culture in thousands of dollars from 2007 is labeled on each county. The 15 counties where $P$. ramorum is known to exist in the wild lands are shaded. $P$. ramorum was found in Trinity County after this study was completed. 
Table 1. Frequency of Phytophthora ramorum positive-determinations collected from forest and nursery locations from 2004 to 2009 by county and submitted to the California Department of Food and Agriculture Laboratory ${ }^{\mathrm{a}}$

\begin{tabular}{|c|c|c|c|c|c|}
\hline \multirow[b]{2}{*}{ County $^{\mathbf{a}}$} & \multicolumn{3}{|c|}{$\begin{array}{c}\text { Frequency of } P \text {. ramorum-positive } \\
\text { determinations }{ }^{\text {a }}\end{array}$} & \multirow[b]{2}{*}{ Total samples collected } & \multirow[b]{2}{*}{ P. ramorum positive (\%) } \\
\hline & Forest & Nursery & Total & & \\
\hline Alameda & 46 & 92 & 138 & 839 & 16.45 \\
\hline Amador & 0 & 0 & 0 & 132 & 0.00 \\
\hline Butte & 0 & 0 & 0 & 1,288 & 0.00 \\
\hline Calaveras & 0 & 0 & 0 & 248 & 0.00 \\
\hline Contra Costa & 18 & 14 & 32 & 2,282 & 1.40 \\
\hline Del Norte & 0 & 0 & 0 & 1,022 & 0.00 \\
\hline El Dorado & 0 & 6 & 6 & 73 & 8.22 \\
\hline Fresno & 0 & 2 & 2 & 2,131 & 0.09 \\
\hline Glenn & 0 & 0 & 0 & 1 & 0.00 \\
\hline Humboldt & 114 & 13 & 127 & 3,459 & 3.67 \\
\hline Imperial & 0 & 0 & 0 & 44 & 0.00 \\
\hline Kern & 0 & 0 & 0 & 2,257 & 0.00 \\
\hline Kings & 0 & 0 & 0 & 7 & 0.00 \\
\hline Lake & 0 & 0 & 0 & 62 & 0.00 \\
\hline Los Angeles & 1 & 42 & 43 & 19,190 & 0.21 \\
\hline Madera & 0 & 1 & 1 & 337 & 0.30 \\
\hline Marin & 164 & 2 & 166 & 399 & 41.60 \\
\hline Mendocino & 59 & 15 & 74 & 1,541 & 4.80 \\
\hline Merced & 0 & 0 & 0 & 50 & 0.00 \\
\hline Monterey & 87 & 2 & 87 & 974 & 9.14 \\
\hline Napa & 10 & 3 & 13 & 125 & 10.40 \\
\hline Nevada & 0 & 20 & 20 & 156 & 12.82 \\
\hline Orange & 0 & 4 & 4 & 5,058 & 0.08 \\
\hline Placer & 0 & 8 & 8 & 1,493 & 0.54 \\
\hline Plumas & 0 & 0 & 0 & 1 & 0.00 \\
\hline Riverside & 0 & 6 & 6 & 23,621 & 0.03 \\
\hline Sacramento & 0 & 65 & 65 & 3,412 & 1.90 \\
\hline San Benito & 0 & 0 & 0 & 192 & 0.00 \\
\hline San Bernardino & 0 & 0 & 0 & 2,557 & 0.00 \\
\hline San Diego & 0 & 17 & 18 & 22,680 & 0.08 \\
\hline San Francisco & 10 & 0 & 10 & 25 & 40.00 \\
\hline San Joaquin & 0 & 11 & 11 & 1,180 & 0.93 \\
\hline San Luis Obispo & 0 & 2 & 2 & 3,785 & 0.05 \\
\hline San Mateo & 246 & 33 & 276 & 746 & 37.40 \\
\hline Santa Barbara & 0 & 4 & 4 & 1,632 & 0.25 \\
\hline Santa Clara & 95 & 32 & 127 & 2,307 & 5.50 \\
\hline Santa Cruz & 41 & 41 & 82 & 3,018 & 2.63 \\
\hline Shasta & 0 & 5 & 5 & 516 & 0.97 \\
\hline Siskiyou & 0 & 0 & 0 & 20 & 0.00 \\
\hline Solano & 24 & 2 & 26 & 1,125 & 2.31 \\
\hline Sonoma & 109 & 30 & 136 & 598 & 23.24 \\
\hline Stanislaus & 0 & 5 & 5 & 2,149 & 0.22 \\
\hline Tehama & 0 & 0 & 0 & 23 & 0.00 \\
\hline Tulare & 1 & 0 & 1 & 1,309 & 0.08 \\
\hline Tuolumne & 0 & 0 & 0 & 6 & 0.00 \\
\hline Ventura & 0 & 5 & 5 & 4,325 & 0.11 \\
\hline Yolo & 0 & 0 & 0 & 8 & 0.00 \\
\hline Yuba & 0 & 0 & 0 & 7 & 0.00 \\
\hline
\end{tabular}

${ }^{\text {a }}$ Counties where P. ramorum had been detected in the forest are in bold.

Table 2. Frequency of Phytophthora ramorum detections from nursery and forest plant samples by year submitted to the California Department of Food and Agriculture Laboratory from June 2004 to May 2009

\begin{tabular}{llccc}
\hline Sample year & Months & P. ramorum-positive samples & Total samples tested & P. ramorum positive $(\%)$ \\
\hline 2004 & June to December & 91 & 7,460 & 1.2 \\
2005 & January to December & 522 & 22,569 & 2.3 \\
2006 & January to December & 374 & 22,324 & 1.7 \\
2007 & January to December & 259 & 24,707 & 1.0 \\
2008 & January to December & 145 & 22,371 & 0.6 \\
2009 & January to May & 112 & 18,959 & 0.6 \\
Total & $\ldots$ & 1,503 & 118,410 & 1.3 \\
\hline
\end{tabular}


not analyzed in detail. The raw data series are subject to a seasonal effect directly related to the fluctuations in monthly sampling intensity (see forest sampling, above). This systematic variation in sampling effort would be likely to induce a corresponding periodicity in the data for numbers of positive diagnoses in each of the tests, and any estimate of a true seasonal variation in the performance of each of the tests needs to be made in the absence of this seasonal sampling effect.

The sampling effect was removed from the data as follows. For each of the series of positives results for each test and the series for "final determination", a simple linear regression was fitted with the number of negative samples, specific to each test, in each month as the explanatory variable. The residuals from these regressions were then used as the data series to study the ACF of the nursery and forest time series. The rationale for this approach is that the negative samples and positive samples together form the total sample size each month, with the negatives in the majority. Therefore, the series for the negative results are a good indicator for the seasonal fluctuation in sampling effort. By regressing the positive cases on negative samples, the variation in the positive results explainable by the seasonal fluctuation in sampling effort is removed from the data for positive cases. The resulting residuals contain any remaining autocorrelation in the data series combined with unmeasured random effects. Following the removal of the seasonal effect, the ACF for time series for the forest and nursery confirmed cases were calculated for each of the tests. The default parameters in $\mathrm{R}$ were used in all cases.

\section{Results}

Sample distribution within the state. An average of 1,380 nursery growing grounds were tested for $P$. ramorum every year from June 2004 to May 2009 in our laboratory. Samples were received from 48 of 58 California counties (Fig. 2). The majority of the nursery samples $(57.8 \%)$ were sent from three southern counties: San Diego, Riverside, and Los Angeles. Samples from the forest were sent from the 14 infested counties, with two exceptions (Table 1). Over the time of this study, $P$. ramorum was detected at least once in each of 30 counties, 17 times from counties without the pathogen in the wild lands.

From June 2004 to May of 2009, 118,410 samples were tested for $P$. ramorum. Of these, $1.3 \%$ tested positive. Percentages of infected samples ranged from a high of $2.3 \%$ in 2005 to $0.6 \%$ in 2008 and 2009 (Table 2). Camellia spp., Rhododendron spp., Magnolia spp., Pieris spp., and Laurus nobilis were the species that tested positive the most frequently in the nurseries and Lithocarpus densiflorus, U. californica, and Q. agrifolia were the species that tested positive most often in samples taken from the forest (Table 3). Overall, 68\% samples that tested positive for $P$. ramorum were submitted from the forests of infested counties (Table 3) even though this represented approximately $3 \%$ of the total samples submitted (data not shown). Rhododendron spp. accounted for $51 \%$ of the positive detections by the USDA testing lab, with Rhododendron, Camellia, Viburnum, and Pieris spp. accounting for $82 \%$ of the hosts which tested positive for P. ramorum (Fig. 3).

Test results: ELISA, isolation, and PCR. Of 115,056 samples tested by ELISA, 5.9\% tested positive for Phytophthora spp. Of the 118,410 isolated onto PARP media, $0.8 \%$ was identified as $P$. ramorum. Of the 6,520 samples tested by PCR, $12.4 \%$ tested positive for $P$. ramorum (Table 4 ). The overall accuracy of the ELISA test in predicting P. ramorum was $6.1 \%$. That is, $6.1 \%$ of the samples that tested positive in the ELISA test, tested positive by either culture or PCR for P. ramorum.

FAM > 36. Of the 237 samples in which the $\mathrm{Ct}$ fell between 36 and 45 for the $P$. ramorum-specific primers in the qPCR test, 77 tested positive by nPCR. There was no correlation $(P>0.05)$ between the actual $\mathrm{Ct}$ values and whether the sample tested positive by nPCR (data not shown). For example, samples with $\mathrm{Ct}$ values closer to 36 were no more or less likely to actually test positive for $P$. ramorum in the nPCR test than those with $\mathrm{Ct}$ values closer to 44 . If a sample was submitted from the forest and the $\mathrm{Ct}>36$, it was $85 \%$ likely to be $P$. ramorum. If a sample was tested from a nursery and the $\mathrm{Ct}>36$, it was only $15 \%$ likely to be $P$. ramorum (data not shown). $P$. hibernalis and $P$. foliorum grew on isolation plates from some of the samples which tested negative.

False negatives. $P$. ramorum grew on culture plates from 7 of 5,711 samples that had tested negative by PCR and positive by ELISA.

False positives. Of 498 samples which initially tested positive by nPCR, 92 were $P$. foliorum and 21 were $P$. hibernalis by RFLP analysis. After January 2007, when the qPCR test was introduced, only five samples tested falsely positive for $P$. ramorum by nPCR and were $P$. foliorum or $P$. hibernalis.

Internal control failures. Amplification of the internal control primers failed 95 times, 24 with the NS1, NS2 primers and 71 times with the cox primers in the qPCR test. The largest numbers of failures were with extracted DNA from Sequoia and Arctostaphylos spp., although extracts from 24 other genera also failed at least once in one of the PCR tests (Table 5).

Time series analysis. A strong regular seasonal effect in sampling, particularly in the nursery samples, resulted from the sampling

Table 3. Frequency of Phytophthora ramorum determinations by host species from nursery and forest samples in California from 2004 until 2009

\begin{tabular}{|c|c|c|c|}
\hline \multirow[b]{2}{*}{ Host } & \multicolumn{3}{|c|}{$\begin{array}{c}\text { Frequency of Phytophthora ramorum } \\
\text { positive determinations }{ }^{\mathrm{a}}\end{array}$} \\
\hline & Nursery & Forest & Tot: \\
\hline Abies concolor ${ }^{\mathrm{b}}$ & 6 & 0 & 6 \\
\hline Arbutus unedo & 3 & 0 & \\
\hline Arctostaphylos spp. & 2 & 1 & \\
\hline Camellia japonica & 129 & 0 & 129 \\
\hline C. sasanqua & 101 & 0 & 101 \\
\hline C. sinensis & 1 & 0 & \\
\hline Camellia spp. & 70 & 0 & 70 \\
\hline Cinnamomum camphora & 1 & 0 & \\
\hline Heteromeles arbutifolia & 5 & 1 & \\
\hline Laurus nobilis & 9 & 0 & \\
\hline Leucothoe fantanesiana & 1 & 0 & \\
\hline Lithocarpus densiflorus & 1 & 51 & 52 \\
\hline Loropetalum chinense & 1 & 0 & \\
\hline Magnolia grandiflora & 7 & 0 & \\
\hline Magnolia sp. & 2 & 0 & \\
\hline Olea europa & 1 & 0 & \\
\hline Nerium oleander & 1 & 0 & \\
\hline Osmanthus fragrans & 5 & 0 & \\
\hline O. heterophyllus & 2 & 0 & 2 \\
\hline Pieris formosa & 1 & 0 & \\
\hline P. japonica & 6 & 0 & \\
\hline Pieris spp. & 4 & 0 & \\
\hline Pittosporum tobira & 1 & 0 & 1 \\
\hline P. undulatum & 7 & 0 & 7 \\
\hline Quercus agrifolia & 0 & 83 & 83 \\
\hline Quercus sp. & 0 & 3 & 3 \\
\hline Rhamnus sp. & 1 & 2 & 3 \\
\hline Rhododendron 'azalea' & 1 & 0 & 1 \\
\hline Rhododendron sp. & 88 & 6 & 94 \\
\hline Sequoia sempervirens & 0 & 2 & 2 \\
\hline Syringa vulgaris & 1 & 0 & 1 \\
\hline Unknown species & 5 & 0 & 5 \\
\hline Umbellularia californica & 14 & 872 & 886 \\
\hline Vancouveria spp. & 1 & 1 & 2 \\
\hline Viburnum tinus & 3 & 0 & 3 \\
\hline
\end{tabular}

a Samples were determined to be positive for $P$. ramorum by culture and/or DNA-based diagnostic. The sampling period was from June 2004 through May 2009 ( $n=118,410$ samples).

b Abies concolor samples were taken from a Christmas tree farm 
guidelines issued to sample collectors (Supplementary Figs. 1 and 2). This seasonal effect resulted in significant ACF values in the nursery and forest autocorrelograms at lags corresponding to an annual cycle; again, the effect was pronounced in the nursery data series (Supplementary Figs. 3 and 4).

Removal of seasonal sampling effect from the data. Regressing the number of positive cases on the number of negative samples produced statistically significant estimates for the explanatory variable for both the forest and nursery samples for each of the tests and the final determination data. Summary statistics for these analyses are given in Supplementary Table 1. The percent variance accounted for by the regressions ranged from $10.4 \%$ in the case of the PCR data from forest samples to $58.2 \%$ in the case of ELISA data from nursery samples. These values give an indication of the extent to which the seasonal fluctuations in sampling effort were correlated with fluctuations in the numbers of positive test results in the raw data.

Time series analysis of seasonally-adjusted data. After removal of the seasonal sampling effect from the data, differences were apparent between the biochemical diagnostic tests (PCR and ELISA) and culture isolation for both the forest and nursery time series (Figs. 4 to 7). For the PCR and ELISA test results for both nursery and forest samples, removal of the seasonal sampling effect removed any significant ACF values except at lag 1 or lag 2 (Figs. 4 and 5). In contrast, for the isolation by culture test, significant autocorrelations were present at lags 11 (nursery only) and 12 (both forest and nursery) (Fig. 6). These results indicate that, independent of the seasonal sampling intensity, there were predictable, periodic fluctuations in the probability of isolating live cultures of $P$ ramorum from the samples submitted to the diagnostic laboratory for evaluation.

An illustration of how the information from different tests was combined to produce a final determination (positive or negative) for P. ramorum from each sample is shown in Figure 7. Not surprisingly, the seasonally adjusted data for the final determinations were intermediate between those for the biochemical diagnostic tests and the isolation by culture procedure.
Particularly in the case of the nursery samples (Fig. 7B and D), there were positive autocorrelations at lags 1,12 , and 13 that approached the upper Bartlett band (i.e., 95\% confidence interval for a zero autocorrelation), indicating that samples collected at equivalent months in successive years tended to have similar status with respect to final determination of $P$. ramorum status regardless of sampling intensity.

\section{Discussion}

Even though there are more than 100 species listed as hosts of $P$. ramorum, relatively few species were detected with the pathogen in the nurseries in California or throughout the United States. The most frequently detected host genera and species found infected with $P$. ramorum in California nurseries from 2004 to 2009 were Camellia, Rhododendron, Magnolia, Pieris, and Laurus nobilis. This contrasts with the most frequently detected host genera found United States wide: Rhododendron, Camellia, Viburnum, Pieris, and Magnolia. The differences may be partially explained by the fact that most of the Rhododendron spp. that are grown in California are evergreen azaleas which are rarely infected with $P$. ramorum. This is in contrast to the larger landscape rhododendrons grown widely in Oregon and Washington. L. nobilis appears on the California list because it is a very

Table 4. Results for individual tests of plant samples for Phytophthora ramorum at the California Department of Food and Agriculture Laboratory from June 2004 to May 2009

\begin{tabular}{lccc}
\hline Assay $^{\mathbf{a}}$ & $\begin{array}{c}\text { Number } \\
\text { positive }\end{array}$ & $\begin{array}{c}\text { Total number } \\
\text { tested }\end{array}$ & $\begin{array}{c}\text { Per cent } \\
\text { positive }\end{array}$ \\
\hline Phytophthora spp., ELISA & 6,844 & 115,056 & 5.9 \\
P. ramorum culture & 977 & 118,410 & 0.8 \\
PCR & 809 & 6,520 & 12.4 \\
\hline
\end{tabular}

a Enzyme-linked immunosorbent assay (ELISA) and polymerase chain reaction (PCR).

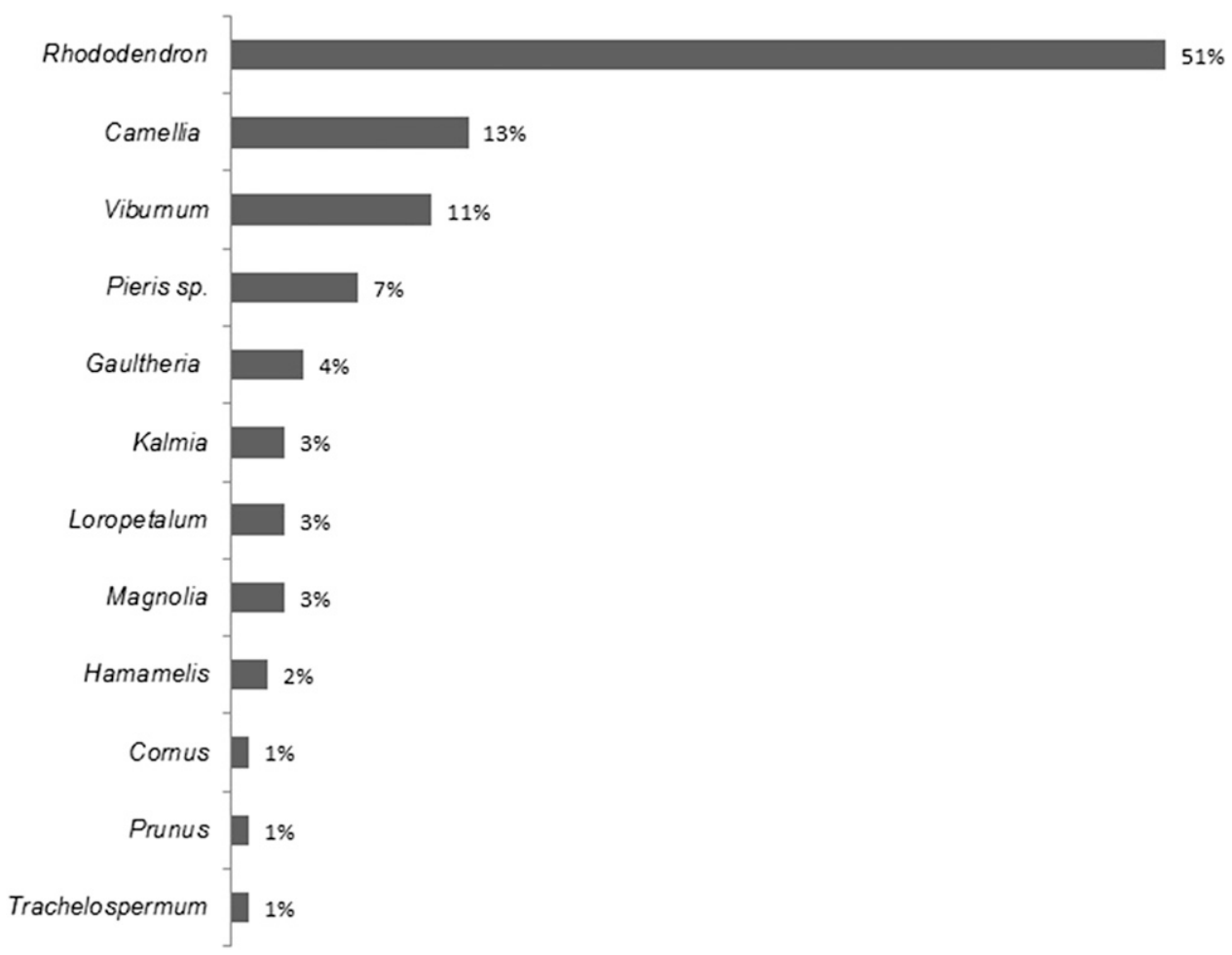

Fig. 3. Percent nursery hosts plant samples sent to the United States Department of Agriculture diagnostic lab for analysis which were confirmed infected with Phytophthora ramorum. 
popular landscape plant and widely grown in frost-free areas of California but not grown through the winter in most parts of the United States.

All of the hosts of $P$. ramorum found infected in the nurseries of California are evergreen plants. Even though deciduous members of the genera Magnolia and Viburnum are grown in the state, the deciduous forms are almost never infected. It is possible that we see little infection of Viburnum spp. in comparison with the rest of the country because the deciduous Viburnum spp. generally leaf out in California after spring rains have ended for the year, when inoculum pressure presumably is lower. In other parts of the United States and Canada which have different rain patterns, deciduous species such as such as witch hazel, dogwood, and Prunus spp. have been infected with $P$. ramorum.

In general, California's climate is coastal or interior. Coastal areas have mild temperatures year round, with summer fog and winter rain. The interior areas have hot dry summers and cool winters with rain. Large wholesale nurseries in California are located in both coastal and interior areas, with the majority located in interior areas in Southern California. Most all are irrigated using overhead sprinklers, with many plant species such as Camellia japonica and Rhododendron spp. grown under shade cloth. Our data suggest that even, though $P$. ramorum is relatively uncommon in the nurseries of California, these microenvironments appear to be conducive to the survival of $P$. ramorum over the summer months.

The general Phytophthora spp. ELISA screened out large numbers of Phytophthora-negative samples quickly and inexpensively. Testing by ELISA reduced the number of samples tested by PCR by $94 \%$. In 2004, we set the cutoff value at twice background below a single culture-positive Camellia sample which tested 2.5 times background in the ELISA test. Since then, Canadian and U.S. regulations have adopted a similar cutoff.

Culture isolation is not required by APHIS regulations in the initial testing procedure and has advantages and disadvantages. With some training, $P$. ramorum can be fairly quickly and easily identified in culture. In addition, if isolates grow in culture, all Phytophthora spp. present in a sample can be identified, not just $P$. ramorum. Observations of what organisms grow in culture can aide in the investigation of possible false-positive PCR tests. Cultures can be genotyped easily, stored in a culture collection, and shared with other investigators. When P. ramorum is present in very small, invisible lesions, the pieces of tissue placed in culture become another sample taken and another chance that $P$. ramorum is detected. This extra sampling probably explains why a few of the samples tested PCR negative and culture positive. We detected P. ramorum on Loropetalum chinense in 2007 for the first time in exactly this scenario (Blomquist et al. 2012).

Unsurprisingly, our results show that culture isolation is not as sensitive a detection method as PCR. Of the 810 samples that tested positive by PCR, $26.54 \%$ were culture negative. $P$. ramorum's ability to grow in culture may be affected by environmental and host conditions in the nursery or forest where the sample was collected. These conditions could include high temperatures, drought stress, or a previous fungicide treatment. A positive PCR test, which depends on intact extractable DNA, is presumably less affected by these factors. In a group of 300 Camellia plants tested from an infected Southern California nursery, $76 \%$ of the plants were nPCR positive whereas only $42 \%$ were culture positive (Bullock et al. 2006). In an early study in Oregon, PCR was not found to be more sensitive than culture but this was possibly because only one punch per leaf was tested for each sample, with a total sample size of 24 (Osterbauer and Trippe 2005). Unfortunately, we did not obtain PCR and culture results for every $P$. ramorum-positive sample for comparison. If a sample was culture positive, resources were not always used to determine whether the sample was also PCR positive.

False positives in the nPCR test, as measured by HaeIII digestion of the nPCR amplicon, were much more common before the use of qPCR in 2007. This may be because the qPCR is incorrect less often than the nPCR, or because there was no obvious alternate method to evaluate whether the qPCR-tested samples were truly positive. The latter seems more likely because $P$. hibernalis and $P$. foliorum tested falsely positive if present in large amounts that were tested in the positive $\mathrm{Ct}$ range from 33 to 36 in qPCR performed during a ring test (Martin et al. 2009). A test using $P$. ramorum-specific primers to a portion of the elicitin gene (Bilodeau et al. 2007) is now available as an additional confirmatory test which does not cross amplify with P. hibernalis or P. foliorum.

DNA extracted from certain host genera such as Sequoia and Arctostaphylos failed to amplify using control primers more frequently than those from other genera. The reason for this is unknown, although polysaccharides and complex phenolic compounds such as humic acids present in plants and decayed plant material have been identified as causes of PCR inhibition in other systems (Rädström et al. 2004; Tebbe and Vahjen 1993). In addition, Taq polymerases vary in sensitivity to inhibitory compounds, with Taq polymerases from some suppliers up to eight times more resistant to inhibitors in one study (Abu and Radstrom 1998). In our laboratory, we are usually able to obtain amplifiable DNA from a failed plant sample by diluting the initial DNA extract, reextracting the plant sample, or extracting a new replacement sample from the same location.

Examining the time series of data for confirmed cases indicated that there is no seasonal component in detection of $P$. ramorum either by ELISA or PCR testing. Under the expectation that the pathogen is easier to detect in samples collected from January through August, a higher proportion of samples was collected each year during this period. However, after removing the seasonal effect of sampling strategy from both the forest and nursery data sets, there was no strong evidence of an underlying seasonal effect in detectability of the pathogen by PCR and ELISA. However, isolation of the pathogen into culture was found to be seasonally dependent and, consequently, so were the data for final determination of pathogen

Table 5. Frequency plant host species failures to amplify the internal control primers in either the conventional or real-time polymerase chain reaction (PCR) test for Phytophthora ramorum

\begin{tabular}{lccc}
\hline Host & Conventional PCR & Real-time PCR & Total \\
\hline Sequoia spp. & 3 & 14 & 17 \\
Arctostaphylos spp. & 5 & 11 & 16 \\
Camellia spp. & 2 & 7 & 9 \\
Heteromeles arbutifolia & 0 & 8 & 8 \\
Arbutus unedo & 3 & 4 & 7 \\
Rhododendron spp. & 3 & 4 & 7 \\
Umbellularia californica & 3 & 1 & 4 \\
Photinia fraseri & 0 & 3 & 3 \\
Quercus spp. & 0 & 3 & 3 \\
Podocarpus spp. & 0 & 2 & 2 \\
Rhus integrifolia & 0 & 2 & 2 \\
Unknown & 1 & 1 & 2 \\
Viburnum sp. & 1 & 1 & 2 \\
Morus nigra & 1 & 0 & 1 \\
Pittosporum undulatum & 1 & 0 & 1 \\
Melaleuca sp. & 1 & 0 & 1 \\
Begonia sp. & 0 & 1 & 1 \\
Abies sp. & 0 & 1 & 1 \\
Adiantum aleuticum & 0 & 1 & 1 \\
Hemerocallis sp. & 0 & 1 & 1 \\
Ilex sp. & 0 & 1 & 1 \\
Leucothoe fontanesiana & 0 & 1 & 1 \\
Loropetalum chinense & 0 & 1 & 1 \\
Malosma laurina & 0 & 1 & 1 \\
Pelargonium sp. & 0 & 1 & 1 \\
Rumohra adiantiformis & 0 & 1 & 1 \\
\hline
\end{tabular}


A

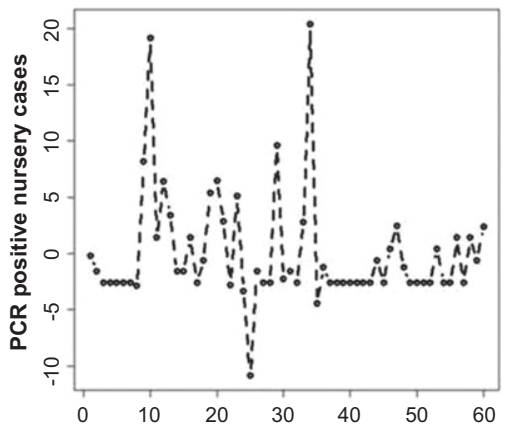

Month in sample sequence

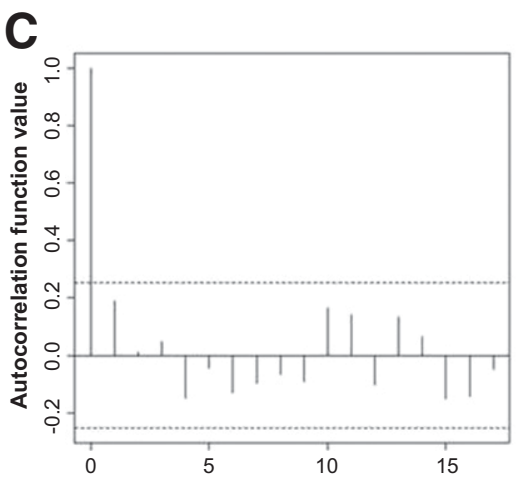

B

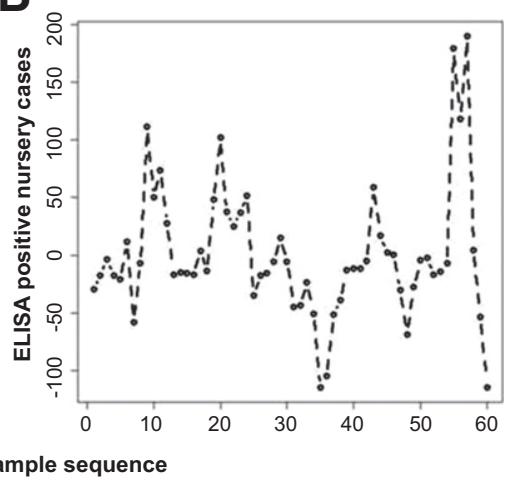

D

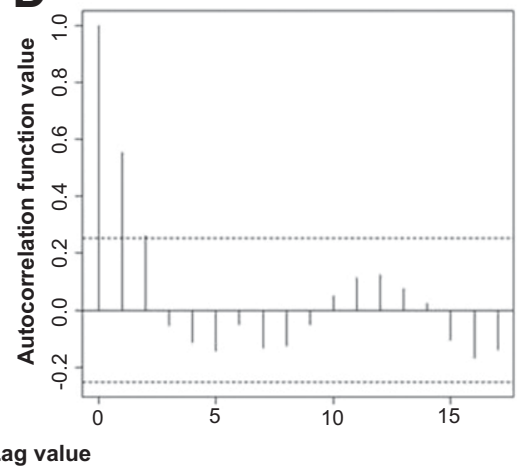

Fig. 4. Seasonally adjusted time series and corresponding autocorrelations for $\mathbf{A}$ and $\mathbf{C}$, polymerase chain reaction (PCR) and $\mathbf{B}$ and $\mathbf{D}$, enzyme-linked immunosorbent assay (ELISA) positive samples from nurseries. Horizontal lines in the autocorrelograms indicate the Bartlett band $95 \%$ confidence interval for a zero correlation. Bars crossing the Bartlett band thresholds indicate the presence of significant autocorrelations between samples collected at the interval indicated on the horizontal axis. For example, in the nursery samples, pathogen status as indicated by ELISA was significantly correlated between adjacent months (i.e., at lag 1) in the data series.
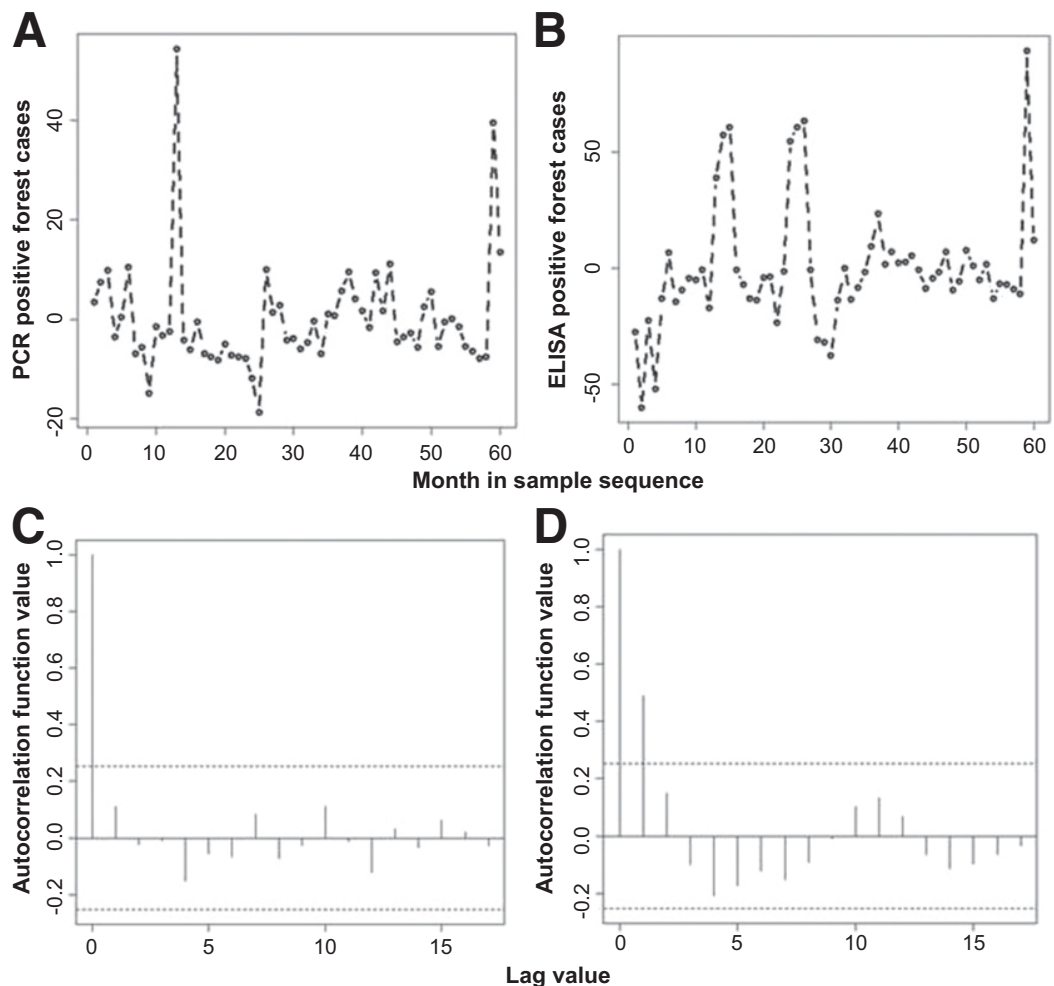

Fig. 5. Seasonally adjusted time series and corresponding autocorrelations for $\mathbf{A}$ and $\mathbf{C}$, polymerase chain reaction (PCR) and $\mathbf{B}$ and $\mathbf{D}$, enzyme-linked immunosorbent assay (ELISA) positive samples from forests. Horizontal lines in the autocorrelograms indicate the Bartlett band 95\% confidence interval for a zero correlation. Bars crossing the Bartlett band thresholds indicate the presence of significant autocorrelations between samples collected at the interval indicated on the horizontal axis. ELISA samples show significant correlation between adjacent months in the series. 

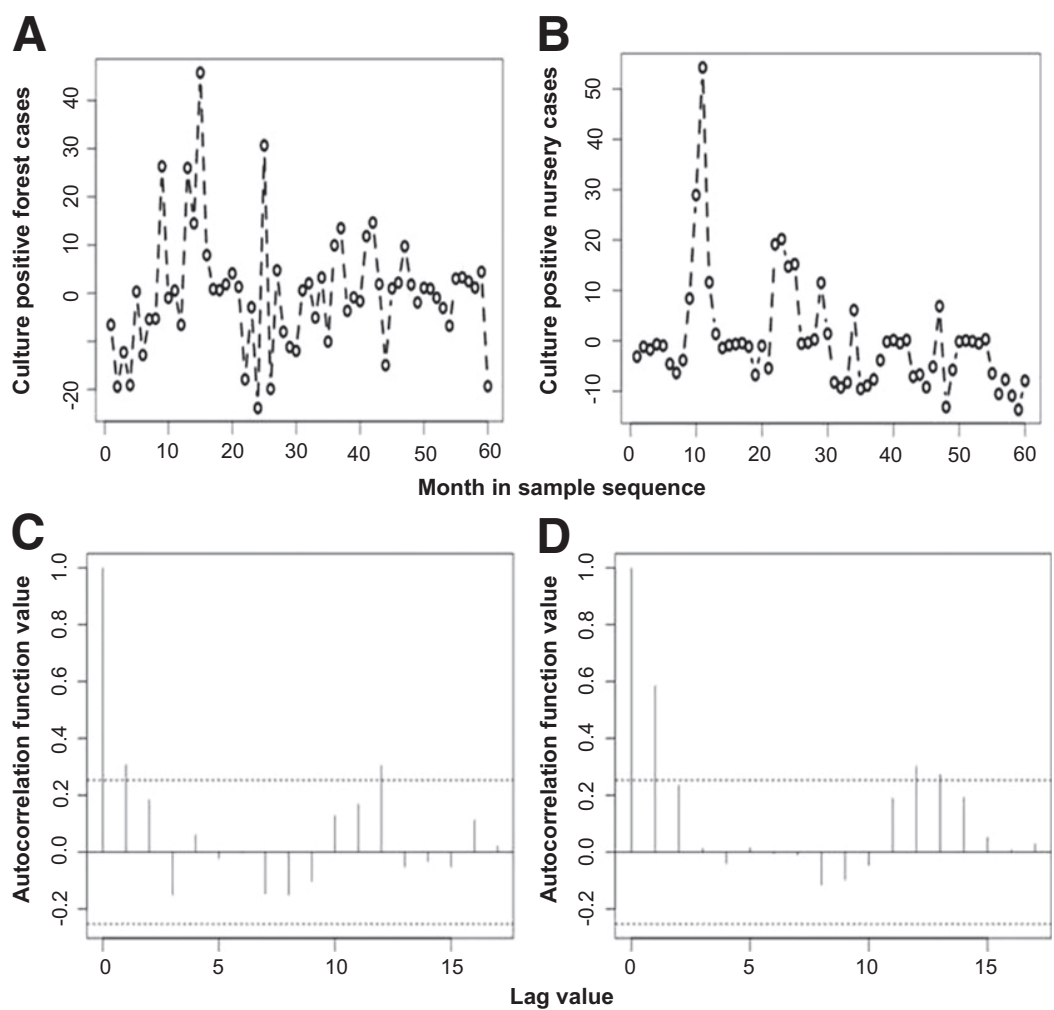

Fig. 6. Seasonally adjusted time series and corresponding autocorrelations for isolation into culture for $\mathbf{A}$ and $\mathbf{C}$, forest and $\mathbf{B}$ and $\mathbf{D}$, nursery positive samples. Horizontal lines in the autocorrelograms indicate the Bartlett band $95 \%$ confidence interval for a zero correlation. Nursery samples show significant autocorrelation at lags 1, 12, and 13 . Forest samples show significant autocorrelation at lags 1 and 12.
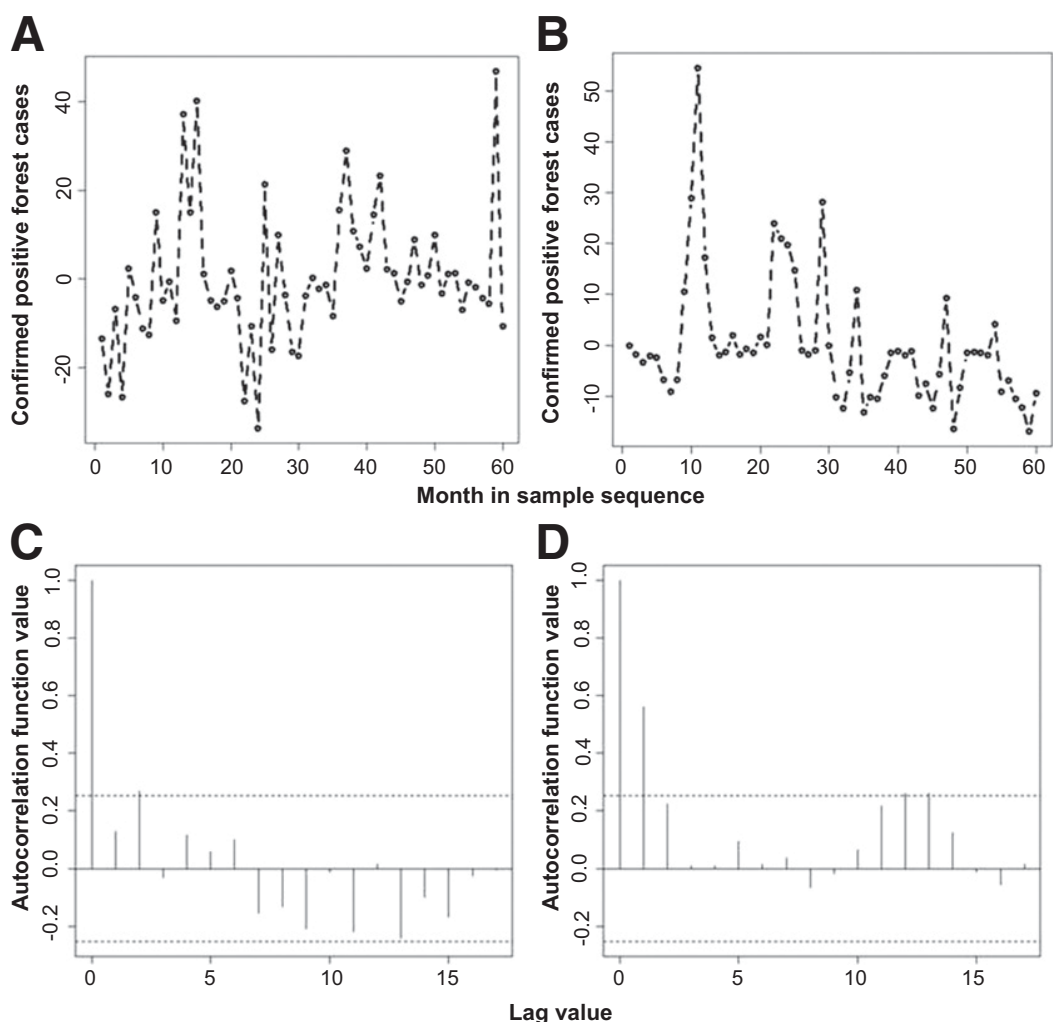

Fig. 7. Seasonally adjusted time series and corresponding autocorrelations for final determination of pathogen status for $\mathbf{A}$ and $\mathbf{C}$, forest and $\mathbf{B}$ and $\mathbf{D}$, nursery positive samples. Nursery samples show significant autocorrelation at lags 1, 12, and 13. Forest samples show significant autocorrelation at lag 2. 
presence, which include information from all three of the diagnostic procedures.

The data set collected during this study is a unique resource of information on the dynamics of $P$. ramorum in California, and the analysis presented here was intended only to examine one question about those dynamics, focused on the issue of detectability. More detailed analysis and statistical modeling of the data set is clearly possible, particularly by connecting it with corresponding weather data, but such analyses are beyond the scope of this report. To our knowledge, this is the first analysis of using time series analysis on a large plant diagnostic data set spanning a 5-year period. These data are derived from samples collected from wild lands and California nurseries as part of a regulatory response to $P$. ramorum. Further validation and standardization of diagnostic protocols by individual laboratories, the National Plant Diagnostic Network, and the USDAAPHIS-PPQ, together with increased computational capabilities within electronic diagnostic repositories, will provide additional and robust analyses of diagnostic data records like the ones evaluated in this study.

\section{Acknowledgments}

We thank T. Walber, E. Lovig, M. Negrete, A. Noguchi, J. Estoque, and M. Soriano for excellent technical assistance; C. Murphy for her help in preparing the map of California; V. Da, I. Mohammed, and E. Holmes for assembling years of laboratory data into spreadsheets; S. Thomas for morphological determinations early in the study; USDA-APHIS PPQ for providing funding for the testing done in our laboratory; and P. Hebbar for providing host testing information from the USDA-APHIS laboratory in Beltsville, MD.

\section{Literature Cited}

Abu Al-Soud, W., and Rädström, P. 1998. Capacity of nine thermostable DNA polymerases to mediate DNA amplification in the presence of PCR-inhibiting samples. Appl. Environ. Microbiol. 64:3748-3753.

Anonymous. 2011. California Agricultural Statistics. Annual issues, 1993 to 2010. U.S. Department of Agriculture, National Agricultural Statistics Service, California Field Office, Sacramento. Online publication. www.nass.usda. gov/Statistics_by_State/California/Publications/California_Ag_Statistics/Reports/.

Anonymous. 2014. Current, APHIS Revises Phytophthora ramorum domestic quarantine regulatory requirements for certain host nurseries. USDA-APHIS PPQ. Online publication. http://www.aphis.usda.gov/plant_health/plant_pest_ info/pram/downloads/pdf_files/DA-2014-02.pdf

Bilodeau, G. J., Lévesque, C. A., de Cock, A. W. A. M., Duchaine, C., Brière, S., Uribe, P., Martin, F. N., and Hamelin, R. C. 2007. Molecular detection of Phytophthora ramorum by real-time polymerase chain reaction using TaqMan, SYBR Green, and molecular beacons. Phytopathology 97:632-642.

Blomquist, C., Irving, T., Osterbauer, N., and Reeser, P. 2005. Phytophthora hibernalis: A new pathogen of rhododendron and evidence of cross amplification with two PCR detection assays for Phytophthora ramorum. Online publication. Plant Health Prog. doi: 10.1094/PHP-2005-0728-01-HN

Blomquist, C. L., Rooney-Latham, S. Soriano, M. C., and McCarty, J. C. 2012. First report of Phytophthora ramorum causing a leafspot on Loropetalum chinense, Chinese fringe flower in California. Plant Dis. 96:1829.2.

Brasier, C. M., and Webber, J. 2010. Sudden Larch Death. Nature 466:824-825.

Bullock, R., Shiel, P., Berger, P., Kaplan, D., Parr, G., Li, W., Levy, L., Keller, J., Reddy, M., Sharma, N., Dennis, M., Stack, J., Pierzynski, J., O’Mara, J., Webb, C., Finnley, L., Lamour, K., McKemy, J., and Palm, M. 2006. A comparative analysis of detection techniques used in US regulatory programs to determine presence of Phytophthora ramorum in Camellia japonica 'Nucio's Gem' in an infested nursery in Southern California. Online publication. Plant Health Prog. doi: 10.1094/PHP-2006-1016-01-RS

Chastagner, G., Oak, S., Omdal, D., Ramsey-Kroll, A., Coats, K., Valachovic, Y., Lee, C., Hwang, J., Jeffers, S., and Elliott, M. 2010. Spread of P. ramorum from nurseries into waterways-implications for pathogen establishment in new areas. In: Proc. Sudden Oak Death Fourth Sci. Symp. Gen. Tech. Rep. PSW-GTR-229. S. J. Frankel, J. T. Kliejunas, and K. M. Palmieri, tech. coords. United States Department of Agriculture, Forest Service, Pacific Southwest Research Station, Albany, CA.

Crawley, M. 2013. The R Book, 2nd ed. John Wiley \& Sons, London.

Davidson, J. M., Werres, S., Garbelotto, M., Hansen, E. M., and Rizzo, D. M. 2003 Sudden oak death and associated diseases caused by Phytophthora ramorum Online publication. Plant Health Prog. doi: 10.1094/PHP-2003-0707-01-DG

Donahoo, R., Blomquist, C. L., Thomas, S. L., Moulton, J. K., Cooke, D. E. L., and Lamour, K. H. 2006. Phytophthora foliorum sp. nov., a new species causing leaf blight of azalea. Mycol. Res. 110:1309-1322.

Erwin, D. C., and Ribeiro, O. K. 1996. Phytophthora Diseases Worldwide. American Phytopathological Society, St. Paul, MN.

Frankel, S. J., and Hansen, E. M. 2011. Forest Phytophthora diseases in the Americas: 2007 - 2010. N. Z. J. For. Sci. 41 (Suppl.):S159-S167.

Grunwald, J. C., Gross, E. M., and Press, C. M. 2008. Phytophthora ramorum: A pathogen with a remarkably wide host- range causing sudden oak death on oaks and ramorum blight on woody ornamentals. Mol. Plant Pathol. 9:729-740.

Hayden, K. J., Rizzo, D., Tse, J., and Garbelotto, M. 2004. Detection and quantification of Phytophthora ramorum from California forests using a realtime polymerase chain reaction assay. Phytopathology 94:1075-1083.

Hughes, K. J. D., Tomlinson, J. A., Griffin, R. L., Boonham, N., Inman, A. J., and Lane, C. R. 2006. Development of a one-step real-time polymerase chain reaction assay for diagnosis of Phytophthora ramorum. Phytopathology 96:975-981.

Jeffers, S. N., and Martin, S. B. 1986. Comparison of two media selective for Phytophthora and Pythium species. Plant Dis. 70:1038-1043.

Martin, F. N., Coffey, M. D., Zeller, K., Hamelin, R. C., Tooley, P., Garbelotto, M., Hughes, K. J. D., Kubisiak, T., Bilodeau, G. J., Levy, L., Blomquist, C., and Berger, P. H. 2009. Evaluation of molecular markers for Phytophthora ramorum detection and identification: Testing for specificity using a standardized library of isolates. Phytopathology 99:390-403.

Osterbauer, N., and Trippe, A. 2005. Comparing diagnostic protocols for Phytophthora ramorum in rhododendron leaves. Online publication. Plant Health Prog. doi: 10.1094/PHP-2005-0314-01-HN

Rädström, P., Knutsson, R., Wolffs, P., Lövenklev, M., and Löfström, C. 2004 Pre-PCR processing, strategies to generate PCR-compatible samples. Mol. Biotechnol. 26:133-146

Rizzo, D. M., Garbelotto, M., and Hansen, E. M. 2005. Phytophthora ramorum: Integrative research and management of an emerging pathogen in California and Oregon forests. Annu. Rev. Phytopathol. 43:309-335.

Royama, T. 1992. Analytical Population Dynamics. Springer, Dordrecht, The Netherlands.

Tebbe, C., and Vahjen, W. 1993. Interference of humic acids and DNA extracted directly from soil in detection and transformation of recombinant DNA from bacteria and a yeast. Appl. Environ. Microbiol. 59:2657-2665.

Waterhouse, G. M., and Waterston, J. M. 1964. Phytophthora hibernalis. No. 31 Descriptions of Plant Pathogenic Fungi and Bacteria. Commonwealth Mycol. Inst., Kew, UK

Webber, J. F., Mullett, M., and Brasier, C. M. 2010. Dieback and mortality of plantation Japanese larch (Larix kaempferi) associated with infection by Phytophthora ramorum. Online publication. New Dis. Rep. 22:19.

Werres, S., Marwitz, R., Man In't Veld, W. A., De Cock, A. W. A. M., Bonants, P. J. M., De Weerdt, M., Themann, K., Ilieva, E., and Baayen, R. P. 2001 Phytophthora ramorum sp. nov., a new pathogen on Rhododendron and Viburnum. Mycol. Res. 105:1155-1165.

Winton, L. M., and Hansen, E. M. 2001. Molecular diagnosis of Phytophthora lateralis in trees, water, and foliage baits using multiplex polymerase chain reaction. For. Pathol. 31:275-283. 